\begin{tabular}{lll}
\hline VOLUME 21 & No. 3, 28 Desember 2015 & Halaman 163-174 \\
\hline
\end{tabular}

\title{
PENDIDIKAN SEKSUAL DALAM MEMBENTUK PERILAKU SEKSUAL POSITIF PADA REMAJA DAN IMPLIKASINYA TERHADAP KETAHANAN PSIKOLOGI REMAJA
}

\author{
Leafio Rinta \\ BKKBN Provinsi Sumatera Utara \\ Email: leafio.rinta@gmail.com
}

\begin{abstract}
The purpose of this study was to found and determined the role and impact of sexual education in forming positive sexual behavior of adolescents and its implications for adolescent psychological resilience.

This study used a qualitative approach with grounded theory procedures. Collecting data used in-depth interviews in seven informen which consisted by five guidance and counseling teacher and the rest was student which active as a peer counselor at the Adolescents Information and Counseling Center. The data was analyzed through the coding phase namely open coding, and axial coding.

The results of this study demonstrated the role of sexual education in support of adolescent psychological resilience was (1) in answering the curiosity of youth by providing appropriate information about adolescent sexuality and (2) in forming a positive attitude in facing early and premarital adolescent sexual behavior. The impact of sexual education for adolescent psychological resilience was ultimately created adolescents that had positive sexual behaviour and created psychological resilience in terms of adolescent sexual behavior.
\end{abstract}

Keywords: Sexual Education, Positive Sexual Behaviour, Adolescent Psychological Resilience

\begin{abstract}
ABSTRAK
Tujuan penelitian ini ialah menemukan dan mengkaji peran dan dampak pendidikan seksual dalam membentuk perilaku seksual positif pada remaja dan implikasinya terhadap ketahanan psikologi remaja.

Penelitian ini menggunakan metode kualitatif dengan pendekatan grounded theory. Data penelitian didapat dari wawancara mendalam pada tujuh orang informan yang terdiri atas lima orang guru yang menangani Bimbingan Konseling (BK) dan sisanya merupakan siswa yang aktif sebagai konselor sebaya di Pusat Informasi dan Konseling Remaja. Analisis data melalui tahap pengkodean, yaitu open coding, dan axial coding.

Hasil penelitian ini menunjukkan ada dua peran pendidikan seksual bagi ketahanan psikologi remaja, yaitu (1) menjawab rasa ingin tahu remaja melalui pemberian informasi yang benar berkaitan dengan seksualitas dan (2) membentuk sikap positif remaja dalam menghadapi perilaku seksual dini dan pranikah. Dampak pendidikan seksual bagi ketahanan psikologi remaja ialah terciptanya remaja yang memiliki perilaku seksual yang positif dan menciptakan ketahanan psikologis remaja dalam hal perilaku seksual.
\end{abstract}

Kata Kunci: Pendidikan Seksual, Perilaku Seksual Positif, Ketahanan Psikologi Remaja 


\section{PENGANTAR}

Masa remaja merupakan masa yang penuh rasa ingin tahu terhadap segala hal, termasuk salah satunya masalah seksual. Pada masa ini remaja membutuhkan bimbingan dalam bentuk pendidikan seksual dalam pembentukan pribadinya baik dengan orangtua maupun lingkungan. Pendidikan seksual ini juga termasuk dalam hubungan baru yang lebih matang dengan lawan jenis. Pada masa ini informasi tentang masalah seksual sudah seharusnya mulai diberikan untuk menghindari agar remaja tidak mencari informasi sendiri dari teman atau sumber-sumber lain yang tidak jelas atau bahkan keliru sama sekali.

Remaja yang merupakan salah satu komponen dari gatra demografi pada astagatra ketahanan nasional, memiliki pengaruh yang besar bagi keberlangsungan kehidupan Indonesia. Pendataan keluarga yang dilaksanakan oleh BKKBN pada tahun 2012 menunjukkan bahwa jumlah remaja yang berusia 16 - 21 tahun di Indonesia sebanyak 29.855.479 jiwa atau sebesar 12,55\% dari jumlah penduduk Indonesia (BKKBN, 2013). Data tersebut juga menunjukkan bahwa demikian besar jumlah remaja yang harus disiapkan untuk membangun Indonesia 10 - 20 tahun mendatang. Jika Indonesia berhasil mendidik para remajanya saat ini untuk mampu mengekspresikan gairah masa mudanya dengan hal yang positif, jauh dari perilaku seksual pranikah, dan bertanggung jawab penuh dengan aktivitas seksualnya baik dari segi agama, biologi, dan moral, maka sangat mungkin Indonesia di masa depan akan menjadi negara yang sejahtera. Namun tidak ada yang bisa diharapkan jika remaja Indonesia sibuk dengan perilaku seks bebas dan perilaku seksual pranikah.
Khisbiyah (1994) meneliti perubahanperubahan mendasar dalam sikap dan perilaku seksual dan reproduksi di kalangan remaja yang telah menjadi salah satu masalah sosial yang memicu keprihatinan masyarakat. Salah satu akibat dari perubahan-perubahan tersebut ialah tingginya tingkat kehamilan di luar nikah pada remaja. Fuad (1998) meneliti mengenai perilaku seksual berisiko tinggi terjangkit HIV/AIDS pada remaja. Hasil dari penelitian ini menunjukkan bahwa pendidikan seksual dapat digunakan sebagai salah satu alternatif pendekatan untuk pencegahan penularan HIV/ AIDS. Adanya beberapa hambatan ataupun masalah dalam kegiatan pendidikan seksual memungkinkan tidak adanya pengaruh pendidikan kesehatan seksual terhadap sikap remaja dalam upaya pencegahan penularan HIV/AIDS. Masalah tersebut ialah yang menyangkut kurangnya dukungan guru, fasilitator yang kurang tepat, dan materi yang kurang berkembang.

Penelitian lainnya dilakukan oleh Novita (2006) yang melakukan penelitian terhadap remaja dan mencari apakah ada hubungan antara perilaku seksual remaja dengan komunikasi dengan orang tuanya. Novita menyimpulkan bahwa orang tua wajib meluruskan informasi yang tidak benar yang dipaparkan oleh media dan disertai dengan penjelasan mengenai perilaku seks yang salah.

Penelitian lain yang berkaitan dengan penelitian ini ialah studi (You : 2010) yang mengkaji efektivitas pendidikan seksualitas untuk meningkatkan kontrol diri terhadap perilaku seks remaja seminari. Menurut You, antara pendidikan seks dan kontrol diri memiliki hubungan implikatif, dimana kontrol diri terbentuk melalui pendidikan 
seksual sebagai hasil proses kognitif dan afektif. Kontrol diri akan mencegah remaja untuk memunculkan perilaku yang impulsif yang mungkin berbahaya bagi remaja dan mengandung konsekuensi negatif. You menyarankan agar program pendidikan seks disusun secara komprehensif dan sesuai dengan kaidah masyarakat dan norma-norma agama.

Hasil studi empiris di atas memberikan petunjuk mengenai permasalahan yang dikaji pada penelitian ini. Sekalipun ada perbedaan konteks antara studi sebelumnya dengan penelitian tesis ini, akan tetapi hubungan antar komponen yang dikaji ada persamaan, yaitu remaja, pengetahuan, dan perilaku seksualnya. Hasil studi sebelumnya menginformasikan bahwa ada kaitan antara komunikasi orang tua dengan remaja. Studi yang dilakukan oleh You membuktikan bahwa kontrol diri yang didapat dari pendidikan seksualitas memiliki implikasi bagi perilaku seksual remaja sementara penelitian Fuad menyimpulkan bahwa meski pendidikan seksual tidak berpengaruh banyak pada perubahan sikap, namun memiliki pengaruh cukup besar terhadap pengetahuan remaja.

Metode yang ditekankan dalam pengumpulan data penelitian ini ialah wawancara mendalam (in-depth interview) dengan topik utama berkaitan dengan pendidikan seksual pada remaja. Wawancara dilakukan pada 7 (tujuh) informan yang berasal dari empat Sekolah Menengah Atas (SMA/MAN) di Kota Yogyakarta, yaitu SMA Negeri 5 Yogyakarta, MAN 1 Yogyakarta, SMA Negeri 11 Yogyakarta, dan SMA Pangudi Luhur Yogyakarta. Pemilihan para informan dilakukan dengan pengambilan sampel bertujuan (purposive sampling), dimana pejabat berwenang di masing-masing lokasi langsung menunjuk guru Bimbingan Konseling (BK) untuk menjadi informan dalam penelitian ini. Selanjutnya beberapa dari guru tersebut menunjuk salah satu siswanya untuk ikut menjadi informan. Adapun tujuan dalam pengambilan sampel ialah memilih informan yang memiliki pengalaman dalam menangani konseling pendidikan seksual dan kesehatan reproduksi remaja, sehingga dipilihlah guru Bimbingan Konseling (BK) dan siswa yang menjadi konselor sebaya di sekolahnya.

\section{PEMBAHASAN}

Peran Pendidikan Seksual Dalam Membentuk Perilaku Seksual Positif Pada Remaja Peran pemberian informasi seksualitas.

Peran tersebut terkait dengan perasaan ingin tahu remaja melalui pemberian informasi yang benar kepada remaja berkaitan dengan seksualitas. Pemberian informasi ini terdiri dari 3 (tiga) komponen yang berhasil diidentifikasi dari hasil wawancara untuk diberikan sebagai materi pendidikan seksual bagi remaja, yaitu informasi yang berkaitan dengan:

Pertama, perubahan dan perkembangan fisik, mental, dan kematangan emosional yang berkaitan dengan masalah seksual pada remaja. Adanya kecenderungan orang tua yang terkesan tidak peduli dengan permasalahan yang dihadapi remaja dalam masa transisinya juga mengakibatkan pendidikan seksual bagi remaja harus diisi dengan materi yang berkaitan dengan gejala-gejala yang dialaminya di masa transisinya. Gejala-gejala tersebut misalnya terjadinya menstruasi bagi remaja putri dan emisi nokturnal (mimpi basah) bagi remaja putra, pertumbuhan rambut pubis, pertumbuhan penis dan payudara, dan lain-lain. 
Melalui materi pendidikan seksual bagi remaja diharapkan agar apa yang tidak didapat anak di rumah, dapat diperolehnya di sekolah. Selain itu, dengan adanya informasi pengetahuan seksual yang berisikan konsep diri, inteligensi, dan juga peran sosial diharapkan remaja dapat lebih baik dalam memilih dan mempercayai teman dan mengerti tentang batasan-batasan dalam pergaulan, sehingga mereka tidak ikut terjerumus dalam pengaruh negatif teman dan lingkungannya. kesalahan dan penyimpangan seksual yang dapat mengganggu kesehatan fisik dan mental remaja.

Kedua, pendidikan seksual juga harus memberikan informasi yang baik dan benar mengenai kesalahan dan penyimpangan seksual yang dapat mengganggu kesehatan fisik dan mental remaja. Kesalahan dan penyimpangan tersebut meliputi beberapa hal yaitu ketergantungan pada pornografi, pacaran sampai melakukan rangkulan dan ciuman, phonesex, dan sharing foto telanjang. Remaja yang sedang dalam proses belajar mengajar, dikarenakan ketergantungannya terhadap pornografi, begitu mudah hilang fokus dari materi yang sedang disampaikan oleh gurunya. Hal ini tentu berpengaruh pada kestabilan prestasi remaja tersebut. Oleh karena itu, remaja perlu diberikan informasi mengenai pornografi yang dapat menyebabkan ketergantungan dan pada akhirnya dapat mengganggu mental dan masa depannya.

Ketiga, dampak negatif pergaulan bebas dan perilaku seksual dini. Remaja perlu diberikan informasi tentang dampak negatif pergaulan bebas dan perilaku seksual dini, seperti kehamilan yang tidak diinginkan (KTD), aborsi, HIV/AIDS, putus sekolah, penyakit menular seksual dan penyakit kelamin. Hal ini disebabkan karena meski sudah ada mata pelajaran biologi yang menjelaskan mengenai kesehatan reproduksi, masih ada remaja yang belum mengetahui hal-hal yang dapat mengakibatkan kehamilan pada remaja dan dampak negatif perilaku seksual dini lainnya. Remaja yang memiliki pengetahuan yang cukup mengenai hal apa saja yang dapat menyebabkan kehamilan beserta dengan risiko atas kehamilannya, tentu tahu bagaimana cara agar tidak hamil, salah satunya adalah dengan meningkatkan kontrol dirinya dalam menghindari perilaku seks bebas maupun seks pra nikah. Cara lainnya ialah dengan selalu mengingat risiko dan tanggung jawab yang harus diembannya apabila dia hamil ataupun menghamili.

Informasi yang benar yang berkaitan dengan seksualitas yang diberikan pada remaja akan menjawab pertanyaan-pertanyaan yang muncul dari rasa ingin tahu pada remaja. Menurut pendapat salah satu informan penelitian ini, informasi-informasi yang berkaitan dengan seksualitas yang didapatnya dari berbagai sumber akurat, memberikan dampak yang positif untuk menjaga rasa ingin tahu terkait dengan seksualitas yang dimilikinya.

Informasi-informasi yang didapat remaja melalui pendidikan seksual mampu menjadi tameng dalam mengontrol rasa ingin tahu yang muncul dalam dirinya. Melalui informasi yang didapatnya tersebut, remaja ini jadi mengerti bahwa apabila dia terus menuruti rasa ingin tahunya, maka kemungkinan dia akan terjerumus dalam perilaku seksual menyimpang seperti seks bebas dan pra nikah.

Informasi yang benar tersebut disampaikan secara sederhana agar dapat dipahami dan dapat diterima oleh setiap remaja 
yang mendengarnya. Hal ini disebabkan karena remaja sebagai objek yang menerima informasi memiliki tingkat pemahaman yang berbeda-beda. Ada remaja yang mengerti materi hanya dengan sekali penyampaian, ada juga yang harus mendengarkan berkali-kali baru bisa mengerti, bahkan ada juga yang salah mengerti materi yang disampaikan.

Kondisi perbedaan tingkat pemahaman inilah yang menjadi salah satu alasan bagi sekolah untuk tidak memberikan pendidikan seksual secara luas kepada remaja. Namun hal ini tidak menjadi alasan agar remaja tidak diberikan pendidikan seksual. Mengingat pentingnya memberikan informasi seluasnya bagi remaja agar terhindar dari rasa penasaran dan ingin mencari tahu ke sumber lain yang belum tentu akurat, hal ini tentu harus dihindari. Pendidikan seksual yang memberikan informasi secara luas mengenai seksualitas bagi remaja tetap harus diberikan, namun dengan cara penyampaian yang lebih sederhana sehingga dapat dicerna oleh seluruh remaja yang menerima informasi tersebut.

\section{Peran pembentukan sikap positif remaja}

Peran pembentukan sikap positif remaja tersebut terkait dengan situasi remaja menghadapi perilaku seksual dini dan pranikah. Hal tersebut dapat dilakukan dengan 2 (dua) cara, yaitu:

Pertama, mengajak remaja untuk menyalurkan energi dan waktunya guna hal-hal yang positif. Kecenderungan terjadinya perilaku seksual menyimpang dapat terjadi salah satunya karena adanya rasa ingin tahu dan waktu luang yang berlebih. Remaja yang sedang berada dalam masa transisi dari anak-anak menuju dewasa selalu dihadapkan pada rasa ingin tahu terhadap berbagai hal. Tidak jarang rasa ingin tahu tersebut tidak mendapatkan jawaban yang masuk ke dalam pikiran remaja baik dari orang tua, guru, maupun lingkungannya. Hal ini menyebabkan remaja tersebut mencari jawaban sendiri yang belum pasti benar dan justru ada kemungkinan menyesatkan. Besarnya rasa ingin tahu yang disertai dengan waktu luang yang banyak dan ketidaktahuan remaja untuk mengisinya dengan kegiatan apa, menyebabkan tidak sedikit remaja yang menghabiskan waktu luangnya untuk mengakses hal-hal yang berbau pornografi di internet. Pada akhirnya, remaja yang memiliki pengetahuan kurang mengenai pendidikan seksual, akan menghabiskan waktunya untuk mengakses hal yang berbau pornografi dan melampiaskan rasa ingin tahunya dengan melakukan onani dan perilaku-perilaku seksual lainnya.

Kedua, mengajak remaja menjauhkan diri dari perilaku seks bebas dan di luar nikah beserta dengan dampak-dampak negatifnya. Melalui informasi dan pemahaman tentang risiko dan tanggung jawab yang harus dipikul remaja yang melakukan penyimpangan seksual, terbentuklah remaja yang mampu mengontrol dirinya dalam hal yang berkaitan dengan seksualitas yang ditimbulkan oleh hormonhormonnya yang sedang berkembang.

\section{Implikasinya Terhadap Ketahanan Psikologi Remaja}

Dalam penelitian ini, berdasarkan hasil wawancara dengan para informan, peneliti menemukan beberapa kriteria ketahanan psikologi yang sejalan dengan kriteriakriteria yang diungkapkan oleh para peneliti sebelumnya. Menurut hasil wawancara didapatkan bahwa remaja yang memiliki ketahanan psikologi memiliki kriteria-kriteria sebagai berikut: 
Pertama, memiliki pengetahuan yang cukup mengenai pendidikan seksual. Salah satu informan penelitian ini menyatakan bahwa remaja yang memiliki ketahanan psikologi merupakan remaja yang pintar dan memiliki pengetahuan yang cukup untuk menghindarkan dirinya dari dampak negatif perilaku seksual. Pendapat yang serupa disampaikan oleh Santrock yang menyatakan bahwa remaja yang memiliki ketahanan psikologi ialah remaja yang memiliki kemampuan untuk memecahkan masalah, kemampuan untuk beradaptasi, dan belajar dari pengalaman hidup sehari-hari (Santrock, 1996). Pengetahuan yang cukup berkaitan dengan pendidikan seksual mengandung unsurunsur yang sama dengan yang dimaksudkan dalam istilah intelektual, yang menggambarkan kemampuan seseorang dalam berpikir dan mengekspresikan keinginan seksualnya ke arah yang positif.

Kedua, mampu menghindarkan dirinya dari perilaku seksual negatif beserta dengan dampak-dampak buruknya. Hasil wawancara menunjukkan bahwa pendidikan seksual mengurangi tingkat kehamilan yang tidak diinginkan pada remaja dan mengurangi tingkat drop out karena perilaku seksual. Hal ini terjadi karena remaja semakin mampu mengontrol dirinya. Hal tersebut sejalan dengan kriteria-kriteria yang diungkapkan oleh peneliti sebelumnya yang menyatakan bahwa seorang remaja yang memiliki ketahanan psikologi mampu mengendalikan emosi, sikap dan menghindarkan dirinya agar tidak terseret dalam lingkungan (Reivich \& Shatte, 2002; MacKay \& Iwasaki, 2005).

Ketiga, memiliki kemampuan untuk menemukan dan menyelesaikan masalah, inisiatif, empati, dan efikasi diri. Empati adalah kemampuan seseorang untuk memahami perspektif orang lain dan membayangkan dirinya berada pada posisi orang tersebut (Gibbs, 2003). Empati merupakan kemampuan individu untuk mengenali perasaan orang lain, hal-hal yang menyebabkan terjadinya perasaan tersebut dan mampu terlibat dalam perasaan emosional tersebut. Sedangkan efikasi diri adalah keyakinan tentang sejauh mana individu memperkirakan kemampuan dirinya dalam melaksanakan tugas atau melakukan suatu tindakan yang diperlukan untuk mencapai suatu hasil tertentu (Bandura, 1997). Efikasi diri diyakini dapat membantu seseorang untuk menentukan seberapa besar usahanya untuk suatu kegiatan, seberapa tekun dalam menghadapi masalah. Semakin besar efikasi diri seseorang, semakin besar usahanya, ketekunannya, dan tingkat daya tahannya (Pajares, 1996)

Dalam penelitian ini, peneliti menemukan bahwa ada informan remaja yang menghadapi sebuah permasalahan dalam penyampaian pengetahuan seksual dari narasumber kepada para remaja. Masalah tersebut terjadi karena adanya perbedaan tingkat pemahaman yang dimiliki masing-masing remaja. Dalam hal ini informan tersebut menemukan sebuah permasalahan dimana dia mengerti dan dapat memahami materi yang diterimanya dalam sebuah seminar yang berkaitan dengan pendidikan seksual, namun ada beberapa temannya yang tidak mengerti materi tersebut. Tanpa ada perintah dari guru maupun orang lain, dia berinisiatif untuk menyampaikan materi sekali lagi kepada teman-temannya agar teman-temannya mendapatkan pemahaman yang sama dengannya. Tindakannya tersebut merupakan suatu perwujudan atas rasa empati dan efikasi diri sesuai dengan kriteria yang disampaikan oleh Reivich dan Shatte yang telah dipaparkan sebelumnya. 
Keempat, memiliki keinginan dan tujuan untuk mempersiapkan masa depan yang baik. Hasil wawancara dengan informan peneliti juga menemukan bahwa remaja yang memiliki ketahanan psikologi, memiliki keinginan dan tujuan untuk mempersiapkan masa depan yang baik. Hal ini dilakukan dengan menetapkan apa tujuan yang ingin dicapainya, dan belajar sungguh-sungguh demi mencapai tujuannya tersebut. Hal ini sejalan dengan pendapat Henderson dan Milstein yang mengungkapkan bahwa remaja yang memiliki ketahanan psikologi merupakan remaja yang memiliki kompetensi sosial serta keterampilan hidup dalam pemecahan masalah, berpikir secara kritis, kemampuan berinisiatif, serta kesadaran akan tujuan yang bersifat positif. Remaja tersebut memiliki minat khusus, memiliki tujuan dan arah serta termotivasi untuk berprestasi di sekolah (Desmita, 2005).

Pengetahuan menjadi sebuah dasar bagi tindakan yang dilakukan individu. Apa yang orang ketahui akan mempengaruhi perilakunya. Pengetahuan merupakan faktor yang penting dalam menentukan perilaku individu (Ajzen, 1985). Pengetahuan dapat secara langsung mempengaruhi perilaku. Sebagai contoh, apabila seorang remaja perempuan mengetahui bahwa setiap hubungan seksual dapat mengakibatkan kehamilan, maka dia akan menghindarkan dirinya dari hubungan seksual. Namun jika dia tidak memiliki pengetahuan mengenai hubungan seksual tersebut, apabila ada ajakan atau dorongan dari luar dirinya, maka bisa jadi dia akan melakukan hubungan seksual tersebut.

Pengetahuan juga dapat mempengaruhi perilaku secara tidak langsung dengan mempengaruhi norma, nilai, sikap, cara pandang, dan efikasi diri seorang remaja. (Ajzen, 1985; Bandura, 1986). Sebagai contoh, apabila remaja tidak mengetahui pandangan orang tuanya mengenai hubungan seksual di kalangan remaja, maka pandangan mereka tentang hubungan seksual di kalangan remaja tersebut akan dibentuk oleh teman dan media. Hal ini akan membuka kesempatan terjadinya perilaku seksual dini pada remaja.

Intensitas komunikasi yang tinggi dengan teman sebaya mengenai seks secara praktis meningkatkan risiko inisiasi hubungan seks pranikah pada usia lebih dini hampir dua kali lipat terutama pada informan lakilaki. Damayanti (2006) menyatakan bahwa perilaku seks pranikah cenderung dilakukan karena pengaruh teman sebaya yang negatif dan pada akhirnya remaja mengadakan percobaan dengan jalan masturbasi, bercumbu atau berhubungan seksual (Hurlock, 1994). Pengetahuan remaja tentang seksualitas dan kesehatan reproduksi terutama didapatkan dari teman sebaya. Adapun topik yang menjadi pembahasan para remaja dengan teman sebayanya ialah cara berhubungan seks, akibat dari hubungan seksual, perkembangan alat reproduksi, dan perilaku seks pranikah. Sumber informasi yang diperoleh dari teman sebaya lebih mudah diterima oleh remaja karena mereka berbicara dengan gaya bahasa yang sama dan menghadapi masalah yang sama. Sesuai dengan teori psikososial menyatakan bahwa pengetahuan dan keterampilan remaja dapat meningkat bila mereka diberi kesempatan untuk meniru perilaku orang yang mempunyai ketertarikan dengannya. Pengaruh teman sebaya dapat menciptakan keterikatan, kebersamaan, sehingga remaja seringkali sulit melepaskan diri dari kelompok teman sebayanya (Handajani, 2001). 
Peran media massa dalam memberikan informasi tentang hal ini juga bisa mempengaruhi perilaku seksual remaja. Nuranti (2009) menyatakan bahwa riwayat terpapar pornografi, intensitas komunikasi tentang seks dengan teman sebaya, dan niat untuk melakukan inisiasi hubungan seks secara praktis meningkatkan risiko perilaku seksual dini pada remaja. Akses remaja terhadap media massa dan pengaruh teman sebaya merupakan faktor karakteristik remaja yang berhubungan dengan sikap remaja terhadap hubungan seksual pranikah.

Jika remaja tidak mengetahui bahwa pornografi dapat merangsang keinginannya untuk melakukan hubungan seksual, maka perilaku mereka akan cenderung semakin tergantung pada pornografi. Namun jika mereka mengetahui tentang hal tersebut, maka mereka akan menghindari paparan pornografi. Kunci untuk meningkatkan pengetahuan guna mengubah perilaku, terutama terletak pada fakta-fakta tersebut di atas, konsepkonsep dan keterampilan yang diperlukan untuk menyampaikan pesan yang menarik tentang perilaku dan memberikan dasar yang diperlukan untuk mengubah sikap, persepsi norma dan keterampilan.

Tingkat pendidikan dan pengetahuan yang baik berhubungan dengan hasil yang baik dan oleh karena itu harus ada sebuah faktor yang bersifat melindungi untuk mencapai hasil yang baik tersebut (Rutter, 1991). Sekolah atau perguruan tinggi menyediakan kesempatan untuk meningkatkan ketahanan, termasuk di dalamnya bertindak sebagai pusat keamanan pelengkap, menyediakan banyak kesempatan untuk mengembangkan diri dan kesempatan untuk membangun hubungan dengan teman sebaya maupun orang dewasa (Garbarino, 1992; Gilligan, 1998).
Ada dua pesan yang harus disampaikan pada remaja sejak dini untuk membangun ketahanan psikologi dalam perilaku seksualnya dan untuk mendukung upaya penundaan perilaku seksual. Pesan pertama ialah bahwa menahan diri merupakan satusatunya cara untuk mencegah terjadinya kehamilan dan penyakit yang tidak diinginkan. Pesan pertama ini perlu disampaikan pada remaja mengingat bahwa tidak sedikit remaja yang salah paham terhadap fakta mengenai kehamilan, konsekuensi dari kehamilan yang tidak diinginkan dan konsekuensi dari menjadi orang tua di masa remaja (Herz \& Reis, 1987). Pesan berikutnya yang harus disampaikan pada remaja sejak dini ialah bahwa pemakaian alkohol merupakan sebuah faktor berisiko yang berkaitan erat dengan perilaku seksual.

Hal ini sesuai dengan pendapat Sarwono (2011) yang menyatakan pendidikan seks bukanlah penerangan tentang seks sematamata. Pendidikan seks sebagaimana pendidikan lain pada umumnya (misalnya Pendidikan Agama atau Pendidikan Moral Pancasila), mengandung pengalihan nilai-nilai dari pendidik ke subjek didik. Dengan demikian informasi tentang seks tidak diberikan telanjang melainkan diberikan secara kontekstual, yaitu dalam kaitannya dengan norma-norma yang berlaku dalam masyarakat, hal-hal yang terlarang, hal-hal yang lazim dan cara melakukannya tanpa melanggar aturan.

Ini menjelaskan bahwa pandangan yang menyatakan bahwa pendidikan seksual merupakan hal yang tabu untuk dibahas dengan remaja merupakan hal yang tidak benar. Minimnya pendidikan seksual di kalangan remaja dituding menjadi penyebab tingginya angka praktek seks di kalangan remaja. Terjadinya kasus-kasus yang berkaitan 
dengan seks yang tidak aman di kalangan remaja sebagian besar dikarenakan kurangnya pengetahuan remaja mengenai masalah tersebut (Chairunna, 2005). Dalam hal ini apabila pengetahuan remaja tentang seksualitas dan kesehatan reproduksi rendah, maka yang beredar di kalangan remaja adalah informasi yang tidak dapat dipertanggungjawabkan. Hurlock (1999) menyatakan bahwa anak yang mendapatkan pendidikan seks dari orang tua atau sekolah cenderung berperilaku seks yang lebih baik daripada anak yang mendapatkan informasi tersebut dari orang lain. Setelah melakukan penelitian yang menguji pengaruh program peningkatan perilaku asertif untuk menolak hubungan seks pranikah bagi remaja dengan melibatkan orang tua. Program peningkatan perilaku asertif ini berhasil apabila memfasilitasi beberapa hal yang sangat penting dalam sebuah pelatihan yang bertujuan untuk mencegah terjadinya perilaku seks pranikah, antara lain dengan mengurangi informasi yang keliru dan menambahkan informasi yang tepat, meningkatkan komunikasi anak dan orang tua.

Salah satu tujuan dari pendidikan kesehatan reproduksi tidak hanya mencegah dampak negatif dari perilaku seksual di usia dini, tetapi juga menekankan pada kebutuhan akan informasi yang benar dan luas tentang perilaku reproduksi serta berusaha memahami seksualitas manusia sebagai bagian penting dari kepribadian yang menyeluruh (Bruess \& Greenberg, 1994). Pernyataan ini mendukung hasil penelitian yang menyatakan bahwa memberikan informasi yang benar kepada remaja yang berkaitan dengan seksualitas dapat mewujudkan ketahanan psikologi bagi remaja.

Hasil penelitian yang dilakukan oleh Zelnik dan Kim (Sarwono, 2011) menyatakan bahwa remaja yang telah mendapatkan pendidikan seks tidak cenderung lebih sering melakukan hubungan seks, tetapi mereka yang belum pernah mendapat pendidikan seks cenderung lebih banyak mengalami kehamilan yang tidak dikehendaki. Pendidikan seks formal yang diberikan pada remaja sebelum mereka melakukan hubungan seksual, secara efektif dapat mengurangi risiko perilaku seksual. Penelitian ini menemukan bahwa pendidikan seksual merupakan hal yang sangat penting bagi kelompok yang berisiko tinggi melakukan hubungan seksual dini dan sangat berisiko tertular penyakit menular seksual.

Berdasarkan penelusuran yang peneliti lakukan, ditemukan bahwa para siswa yang mendapatkan pendidikan seksual yang cukup di sekolahnya merupakan remaja-remaja yang memiliki keempat kriteria ketahanan psikologi remaja. Terlepas dari mana pendidikan seksual yang mereka dapatkan (baik dari instansi pemerintah seperti BKKBN atau Dinas Kesehatan, sekolah, maupun orang tua), remaja yang mendapatkan pendidikan seksual yang cukup, memiliki kompetensi sosial dan keterampilan hidup dalam pemecahan masalah, berpikir secara kritis, kemampuan berinisiatif, serta kesadaran akan tujuan yang bersifat positif dan tetap stabil serta mampu meminimalisir ataupun melawan pengaruh yang bisa merusak kondisi fisik dan kejiwaannya, sesuai dengan pengertian ketahanan psikologi remaja. Remaja yang mendapatkan pendidikan seksual yang baik akan menunjukkan perilaku seksual yang positif. Kumpulan dari seluruh kondisi ini akan menciptakan remaja yang mampu melalui masa remajanya dengan baik dan terhindar dari pergaulan bebas, perilaku seksual dini, dan perilaku seksual pranikah. 
Hasil penelitian ini sejalan dengan beberapa hasil penelitian sebelumnya yang menyimpulkan bahwa pendidikan seksual dapat mencegah terjadinya dampak negatif dari perilaku seksual dini. Pendidikan kesehatan reproduksi yang dituangkan melalui muatan lokal sekolah terbukti efektif dalam meningkatkan pengetahuan remaja tentang pencegahan kehamilan yang tidak diinginkan (Fatimah, 2010). Penelitian yang sama juga menemukan bahwa remaja yang mempunyai pengetahuan pencegahan kehamilan yang tidak diinginkan kategori tinggi lebih banyak ditemukan pada remaja yang mendapat pendidikan kesehatan reproduksi melalui muatan sekolah.

Pendidikan kesehatan reproduksi atau pendidikan seksual secara formal dapat mengubah perilaku, baik menunda atau mengurangi perilaku seksual dini pada remaja (Eisen, 1990). Remaja yang belum melakukan hubungan seks, apabila mendapatkan pendidikan seksual maka cenderung akan menunda hubungan seks pertama mereka. Namun jika sudah terlanjut aktif melakukan hubungan seksual, maka mereka akan menggunakan kontrasepsi atau mengurangi jumlah pasangan (Darling \& Hollon, 2003).

Selain itu, remaja yang tidak setuju dengan hubungan seksual di luar nikah akan mempunyai perlindungan yang kuat dari terjadinya kehamilan yang tidak diinginkan, PMS, dan HIV/AIDS. Pendidikan kesehatan reproduksi atau pendidikan seksual yang komprehensif menjadi sangat penting dan diperlukan dengan banyaknya informasi seksual yang ada baik di internet, televisi, radio, buku, dan majalah. Hal ini disebabkan karena tujuan utama pendidikan kesehatan reproduksi tidak hanya memberikan informasi tentang seksualitas (sesuai peran pertama pendidikan seksual yang dihasilkan penelitian ini) tetapi juga menumbuhkan sikap, perilaku positif, dan refleksi kritis terhadap pengalaman individu.

\section{SIMPULAN}

Berdasar uraian di atas dapat ditarik simpulan sebagai berikut:

Pertama, pendidikan seksual memiliki pengaruh positif terhadap ketahanan psikologi remaja. Remaja yang mendapatkan pendidikan seksual yang cukup, memiliki kemampuan untuk melalui masa remajanya tanpa terjerumus dalam pengaruh negatif perilaku seks bebas dan pranikah.

Kedua, peran pendidikan seksual bagi ketahanan psikologi remaja ialah memberikan informasi yang benar yang berkaitan dengan seksualitas dan membentuk sikap positif remaja dalam menghadapi perilaku seksual dini dan pranikah.

Ketiga, implikasi pendidikan seksual sendiri bagi ketahanan psikologi remaja ialah menciptakan remaja yang tangguh, memiliki pengetahuan yang cukup mengenai pendidikan seksual dan mampu menghindarkan dirinya dari perilaku seksual dini, pergaulan bebas, beserta dengan dampak-dampak negatifnya. Selain itu pendidikan seksual bagi remaja juga akan menciptakan remaja yang memiliki kemampuan untuk menemukan dan menyelesaikan masalah, inisiatif, empati, dan efikasi diri, serta berwawasan kepada menciptakan masa depan yang baik bagi dirinya.

\section{DAFTAR PUSTAKA}

Ajzen, I., 1985, From Intention to Actions: A Theory of Planned Behavior. Dalam 
J. Kuhl and J. Beckman (Eds.). Action Control From Cognition to Behavior. New York: Springer-Verlag Bandura, A., 1986, Social Foundations of Thought and Action, NJ: Prentice Hall Bandura, A., 1997, Self-efficacy: The Exercise of Control, New York: Freeman

BKKBN, 2013, Profil Hasil Pendataan Keluarga Tahun 2012, Jakarta: BKKBN

Bruess, CE., Greenberg, JS., 1994, Sexuality Education: Theory and Practice, Indiana: Brown \& Benchmark

Chairunna, Harjono, Riyatno, P., \& Wahidin, 2005, “Telaah Pengetahuan, Sikap dan Perilaku Remaja tentang Kesehatan Reproduksi”, Warta Demografi Tahun 35(1), 18-24

Damayanti, R., \& Mulyani, T., 2006, Bahan Ajar: Perilaku Berisiko Pada Remaja, Depok: FKM UI

Darling, C.A., \& Hollon, S., 2003, “Family Life Education: Integrating Theory and Practice. In D.J. Bredehoft, \& M.J. Walcheski (Eds.)”. Human Sexuality, 8291, Minneapolis, MN: National Council on Family Relation

Desmita, 2005, Psikologi Perkembangan, Bandung: PT Rosdakarya Offset

Eisen, M., Zellman, G.L., \& McAlister, A.L., 1990, "Evaluating the Impact of Theorybased Sexuality and Contraceptive Education Program”. Family Planning Perspectives, 22(6), 261-271

Fatimah, O., 2010, "Hubungan Pendidikan Kesehatan Reproduksi Melalui Muatan Lokal Sekolah Terhadap Pengetahuan Pencegahan Kehamilan yang Tidak Dinginkan (KTD) pada Remaja SMA di Kabupaten Dompu”, Tesis: Universitas Gadjah Mada
Fuad, C., 1998, "Pengaruh Pendidikan Kesehatan Seksual Terhadap Pengetahuan dan Sikap Remaja dalam Upaya Pencegahan Penularan HIV/ AIDS di Kotamadya Dati II Yogyakarta: Studi pada Remaja SMU dan SMK Kodya Yogyakarta yang Mendapat Pendidikan Kesehatan Seksual Melalui Peer Education oleh PKBI DIY”, Tesis: Universitas Gadjah Mada

Garbarino, J., Dubrow, N., Kosteleny, K., \& Pardo, C., 1992, Children in Danger: Coping with the Consequences of Community Violence, San Francisco: Jossey-Bass

Gibbs, JC., 2003, Moral Development and Reality: Beyond the Theories of Kohlberg and Hoffman, Ohio: SAGE Publication Gilligan, R., 1998, “The Importance of Schools and Teachers in Childwelfare." Child and Family Social Work, 3(1), 13-26

Handajani, Y.S., 2001, “Kehidupan Seksual Remaja di Daerah Kumuh Perkotaan Jakarta”. Majalah Kesehatan Perkotaan, VIII (2)

Herz, EJ., \& Reis, JS., 1987, “Family Life Education For Young Inner-city Teens: Identifying Needs”. Journal of Youth and Adolescence, 16, 361-377

Hurlock, E.B., 1999, Psikologi Perkembangan, Jakarta : Erlangga

Khisbiyah, Y., 1994, “Konsekuensi Psikologis dan Sosial-Ekonomi Kehamilan Tak Dikehendaki pada Remaja”, Populasi, 5(2), 74-88

MacKay, K., \& Iwasaki, Y., 2005, “Buliding Strengths and Resilience: Leisure as A Stress Survival Strategy”. Journal of Guidance \& Counselling, 33(1), 14692534 
Novita, N., Hasanat, N.U.I., \& Supriyati, 2006, "Hubungan Antara Paparan Pornografi dan Komunikasi Remaja - Orang tua dengan Perilaku Seksual di SMA Negeri 11 Palembang”. Sains Kesehatan 2006, XIX(2), 127-136

Nuranti, A., 2009, “Hubungan Antara Komunikasi Orang Rua-Remaja dengan Sikap Remaja Terhadap Hubungan Seksual Pranikah di SMA Kabupaten Purworejo”, Tesis: Universitas Gadjah Mada

Pajares, F., 1996, "Self-efficacy Beliefs in Academic Settings". Review of Educational Research Winter, 66(4), 543-578
Reivich \& Shatte, 2002, The Resilience Factor: 7 Essential Skills For Overcoming Lives Invitable. New York

Rutter, M., 1991, "Pathways from Childhood to Adult Life: The Role of Schooling”, Pastoral Care, September, 3-10

Santrock, J.W., 1996, Adolescence: Student Study Guide, $6^{\text {th }}$ Ed, London: Brown \& Benchmark

Sarwono, S.W., 2011, Psikologi Remaja, Ed. Revisi, Cet. 14, Jakarta: Rajawali Press You, Y., 2010, “Efektivitas Pendidikan Seksualitas untuk Meningkatkan Kontrol Diri Terhadap Perilaku Seks Remaja Seminari”, Tesis: Universitas Gadjah Mada 